Original Article

\title{
ANTICONVULSANT ACTIVITY OF PORTULACA OLERACEA LINN. AND EUPATORIUM BRIMANICUM DC IN MES INDUCED SEIZURE: A COMPARATIVE STUDY
}

\author{
MAYANGLAMBAM MEDHABATI ${ }^{1}$, LAISHRAM BABYCHA ${ }^{2}$, ABHISHEK BHATTACHARJEE ${ }^{3}$, NGANGOM GUNINDRO ${ }^{4}$ \\ 1,3,4 Department of Pharmacology, Regional Institute of Medical Sciences, Imphal, India, ${ }^{2}$ Department of Pharmacology, Jawaharlal Nehru \\ Institute of Medical Sciences, Imphal, India \\ Email: babhishek637@gmail.com
}

Received: 08 Nov 2020, Revised and Accepted: 10 Jan 2021

\section{ABSTRACT}

Objective: The study was aimed to evaluate and compare the anticonvulsant activity of aqueous leave extract of Portulaca oleracea Linn. and Eupatorium brimanicum DC in MES model in albino mice.

Methods: Aqueous Extracts were prepared by the soxhlet extraction method. MES model was chosen to evaluate anticonvulsant activity. 36 albino mice were selected and divided into 6 groups for this model. Group I received 2\% gum acacia $1 \mathrm{ml} / 100 \mathrm{~g}$ orally. Group II received phenytoin-20 $\mathrm{mg} / \mathrm{kg}$ orally. Group III and IV received 200 and $400 \mathrm{mg} / \mathrm{kg}$ of Portulaca oleracea Linn. Respectively. Group V and VI received 200 and $400 \mathrm{mg} / \mathrm{kg}$ of Eupatorium brimanicum DC respectively.

Results: The extracts didn't show any toxicity and significantly reduced hind limb tonic extension (HLTE) duration in MES model (50 mA, 0.2 sec) at higher doses.

Conclusion: The results suggest Portulaca oleracea Linn. and Eupatorium brimanicum DC extract possess anticonvulsant activity and justify their use in folk medicine.

Keywords: MES, Anticonvulsant, Portulaca oleracea Linn., Eupatorium brimanicum DC, Albino mice

(c) 2021 The Authors. Published by Innovare Academic Sciences Pvt Ltd. This is an open access article under the CC BY license (https://creativecommons.org/licenses/by/4.0/)

DOI: https://dx.doi.org/10.22159/ijcpr.2021v13i2.41561. Journal homepage: https://innovareacademics.in/journals/index.php/ijcpr

\section{INTRODUCTION}

Epilepsy is one of the most common neurological disorders which significantly affects the quality of life. It affects 70 million people in the world [1]. Epilepsy refers to a disorder of brain function characterized by the periodic and unpredictable occurrence of seizures. The underlying abnormality of epilepsy is poorly understood, but it may be associated with an imbalance between excitatory and inhibitory neurotransmitters in the brain [2]. The pathologies leading to epilepsy can occur anywhere in the circuit level in brain e. g. from abnormal synaptic connectivity to the receptor level, abnormality of $\gamma$-aminobutyric acid (GABA) receptor subunits and/or ion channel dysfunction [3]. Antiepileptic drug therapy is the mainstay of treatment for most of patients of epilepsy. The overall goal is to completely prevent seizure without causing any untoward side effects. Unfortunately, the drugs used currently not only fail to control seizure activity in approximately $30 \%$ of patients but frequently cause untoward effects like impairment of the CNS, aplastic anaemia, hepatic failure, etc $[4,5]$. In order to overcome such drawbacks, there is a substantial need to develop novel antiepileptic drugs (AEDs) with more efficacy and safety. Moreover, herbal medicines are extensively used globally since ancient times due to their therapeutic efficiency and minimal side effects in nervous system. In recent years, several investigations for the search of novel and better tolerated antiepileptic drugs have progressed with promising results. Many plants are known to possess anticonvulsant property and are commonly used in traditional folklore. However, there is paucity of the anticonvulsant studies of the medicinal plants like Portulaca oleracea Linn. and Eupatorium brimanicum DC in animal models [6, 7]. Therefore, our study aimed to evaluate the anticonvulsant activity of these two medicinal plants in Maximal electroshock (MES) model of epilepsy in albino mice.

\section{MATERIALS AND METHODS}

The study was conducted in the Department of Pharmacology, Regional Institute of Medical Sciences (RIMS), Imphal, after getting approval of the Institutional Animal Ethics Committee (No.1596/GO/a/12/CPCSEA).

\section{Requirements}

Albino mice, polypropylene cages, gavage feeding tube, electroconvulsiometer, ear clip electrodes, stopwatch, gum acacia, phenytoin Sodium (Knoll pharma, India), soxhlet apparatus, mixer grinder, evaporating dish, weighing machine, mortar and pestle.

\section{Preparation of the extract}

Fresh aerial parts of Portulaca oleracea Linn. and Eupatorium Brimanicum DC were collected from the Imphal, Manipur, identified and authenticated by Prof. P. K. Singh, Department of Life Sciences, Manipur University. The plant parts were cleansed, dried under shade. The leaves were separated and powdered by a mixer grinder. The powdered materials of these two plants were extracted separately with distilled water using a Soxhlet apparatus [8]. The extracts were evaporated, scraped out and stored in airtight container. The yields obtained were $35.2 \%$ and $37.13 \%$ for Portulaca oleracea Linn. and Eupatorium brimanicum DC respectively.

\section{Phytochemical screening}

The preliminary phytochemical studies of the extracts were done following standard procedures $[9,10]$

\section{Animals}

Healthy albino mice of either sex weighing 25-30 g were procured from the central animal house of the institute. They were housed in standard polypropylene cages and acclimatized to the laboratory conditions for $7 \mathrm{~d}$ at room temperature with $12 \mathrm{hr}$ light and dark cycle. The mice were given a standard laboratory diet and water ad libitum. Food was withdrawn $8 \mathrm{hr}$ before and during experiments.

\section{Acute toxicity study}

Acute toxicity testing was carried out as per OECD guidelines 423 in albino mice [11]. Three animals were used for each step. The aqueous extracts of Portulaca oleracea Linn. and Eupatorium brimanicum DC were administered to the fasted mice at a dose of $300 \mathrm{mg} / \mathrm{kg}$ (p. o.) and observed once in every $30 \mathrm{~min}$ during the first 
$24 \mathrm{~h}$ and thereafter, daily for $14 \mathrm{~d}$. As there was no mortality, the procedure was repeated with a higher dose of $2000 \mathrm{mg} / \mathrm{kg}$, and the animals were observed for mortality and toxic symptoms. At the dose of $2000 \mathrm{mg} / \mathrm{kg} \mathrm{p}$. o. of the plant extracts, no mortality or toxic symptoms were detected in the tested animals and the dose was considered safe. Two doses of $200 \mathrm{mg} / \mathrm{kg}\left(1 / 10^{\text {th }}\right.$ of the maximum test dose) and $400 \mathrm{mg} / \mathrm{kg}\left(1 / 5^{\text {th }}\right.$ of the maximum test dose) of the plant extracts were selected as working doses for the experiment.

\section{Assessment of anticonvulsant effect}

\section{Selection of animals}

Electroconvulsiometer (Techno Electronics, Lucknow) was used for seizure induction. The mice showing hind limb tonic extension (HLTE) at a current of $50 \mathrm{~mA}$ for $0.2 \mathrm{sec}$ via a pair of ear clip electrodes were selected. HLTE was defined by an extension of hind limb more than $90^{\circ}$ from the body and sustained for more than 3 seconds [12]. A recovery period of $5 \mathrm{~d}$ was given before the main test.

\section{Procedure}

The animals were divided into 6 (six) groups. Each group consisted of 6 (six) animals. The drug treatment schedule of the different groups was demonstrated in table 1.

The mice were subjected to an electrical stimulus of $50 \mathrm{~mA}$ of alternating current from the electroconvulsiometer for $0.2 \mathrm{sec}$ via ear clip electrodes $1 \mathrm{~h}$ after drug administration. The resulting seizure passed through different phases-tonic flexion, tonic extension, clonic convulsions, stupor, and recovery or death [13]. The HLTE phase was recorded and assessed. The reduction or complete of abolition of HLTE phase was considered as protection against convulsion [14].

Table 1: Allotment of animals to different groups and their treatment

\begin{tabular}{ll}
\hline Group & Treatment \\
\hline I (Control) & $2 \%$ Gum acacia, p. o. \\
II (Standard) & Phenytoin Sodium $20 \mathrm{mg} / \mathrm{kg}, \mathrm{p}$. o. dissolved in $2 \%$ Gum acacia \\
III & $200 \mathrm{mg} / \mathrm{kg}$ of Portulaca oleracea, p. o. dissolved in $2 \%$ Gum acacia \\
IV & $400 \mathrm{mg} / \mathrm{kg}$ of Portulaca oleracea, p. o, dissolved in $2 \%$ Gum acacia \\
V & $200 \mathrm{mg} / \mathrm{kg}$ of Eupatorium brimanicum, p. o, dissolved in $2 \%$ Gum acacia \\
VI & $400 \mathrm{mg} / \mathrm{kg}$ of Eupatorium brimanicum, p. o, dissolved in $2 \%$ Gum acacia \\
\hline
\end{tabular}

Standard drug and the plant extracts were suspended in $2 \%$ gum acacia in DW and administered at the dose of $1 \mathrm{ml} / 100 \mathrm{~g}$ orally.

Table 2: Effects of aqueous extract of Portulaca oleracea linn. and Eupatorium brimanicum DC on MES induced seizure in mice

\begin{tabular}{ll}
\hline Treatment group & Duration of HLTE(Sec) \\
\hline I. Control-2\% gum acacia in DW & $15.52 \pm 0.37$ \\
II. (Standard) Phenytoin Sodium $20 \mathrm{mg} / \mathrm{kg}$ & $-13.50 \pm 0.37$ \\
III. $200 \mathrm{mg} / \mathrm{kg}$ of Portulaca oleracea & $10.92 \pm 0.91^{\text {⿴囗十 }}$ \\
IV. $400 \mathrm{mg} / \mathrm{kg}$ of Portulaca oleracea & $13.23 \pm 0.22$ \\
V. $200 \mathrm{mg} / \mathrm{kg}$ of Eupatorium brimanicum & $10.22 \pm 0.32^{\text {⿴囗十 }}$ \\
VI. $400 \mathrm{mg} / \mathrm{kg}$ of Eupatorium brimanicum & 16.06 \\
One way ANOVA & 4 \\
F & $<0.001$ \\
df & \\
\hline
\end{tabular}

$\mathrm{n}=6$ in each group, values are mean $\pm \mathrm{SEM},{ }^{*} \mathrm{p}<0.001$, compared to control, ${ }^{\dagger} \mathrm{p}<0.05$ compared to group III, ${ }^{\star} \mathrm{p}<0.05$ compared to group $\mathrm{V}$.

\section{Statistical analysis}

The results were analyzed for statistical significance using one-way ANOVA followed by Bonferroni test. $\mathrm{P}<0.05$ was considered significant. IBM SPSS statistics version 21 was used for data analysis.

\section{RESULTS}

\section{Phytochemical screening}

The qualitative phytochemical analysis of Portulaca oleracea Linn. and Eupatorium brimanicum DC revealed the presence of alkaloids, flavonoids, saponins and tannins.

Anti-convulsant effects of aqueous extract of Portulaca oleracea Linn. and Eupatorium brimanicum DC on MES induced seizure in mice are shown in table 2.

\section{DISCUSSION}

Research into epilepsy and development of anti-epileptic drugs relies on studies in experimental animals. Mice are commonly used rodents because of smaller size, ease of housing and maintenance. Interestingly, the genetic, biological, and behavioural characteristics of the rodents closely resemble to those of humans [15]. Maximal electroshock (MES) seizure is the mainstay of any antiepileptic drug screening. In this present study, the anticonvulsant activity of Portulaca oleracea Linn. and Eupatorium brimanicum DC were evaluated by maximal electroshock seizure (MES) in albino mice.
The MES is probably the best-validated method for the assessment of anti-epileptic drugs in generalized tonic-clonic seizure [16]. Efficacy in this model was determined by decreased in duration of hind limb tonic extension (HLTE). MES causes several changes at cellular level, which can disrupt the signal transduction in the neurons. One of the most important mechanism by which it causes cellular damage is facilitation of $\mathrm{ca}^{2+}$ entry into the cell in large amount and thus, prolonging the duration of convulsion [17]. Apart from $\mathrm{ca}^{2+}$ ions MES also facilitates the entry of $\mathrm{Na}^{+}$ion. Blockade of these ions can prevent the MES-induced tonic extension [18]. The aqueous extract of Portulaca oleracea Linn. and Eupatorium brimanicum DC were found to possess significant anti-convulsant activity in albino mice at the dose of $400 \mathrm{mg} / \mathrm{kg}$, p. o against MES induced seizure. However, the extract of Eupatorium brimanicum revealed maximum anticonvulsant potential. Mice treated with phenytoin $20 \mathrm{mg} / \mathrm{kg}$ didn't exhibit any HLTE for which the possible anticonvulsant mechanism is inhibition of voltage-sensitive $\mathrm{Na}^{+}$channels in the neurons.

The preliminary phytochemical analysis of Portulaca oleracea Linn. and Eupatorium brimanicum DC showed the presence of flavonoids, alkaloids, saponins and tannins. Several reports suggest that flavonoids and alkaloids have potent anticonvulsant activity in various seizure models [19-21]. Therefore, the presence of such compounds in both the extracts may be responsible for their anticonvulsant potential. This study provides experimental support for the traditional use of these plants for the treatment of epilepsy. 


\section{CONCLUSION}

Results of the present study show that the aqueous extract of Portulaca oleracea linn. and Eupatorium brimanicum DC leaves (400 $\mathrm{mg} / \mathrm{kg}$ ) produced a significant anticonvulsant effect against MES induced seizure in mice. These observations suggest that aqueous extract of Portulaca oleracea Linn. and Eupatorium brimanicum DC possibly act by modulating ion channels in CNS to exert their anticonvulsant effect. However, further research is required to elucidate its specific mechanism of action and active principles responsible for potential anticonvalsant property.

\section{ACKNOWLEDGMENT}

I would like to acknowledge the contribution of Dr. PK Singh, Professor, Department of Life Sciences, Manipur University for his help in identification and authentication of the plants.

\section{FUNDING}

Nil

\section{AUTHORS CONTRIBUTIONS}

All the authors have contributed equally.

\section{CONFLICT OF INTERESTS}

Declared none

\section{REFERENCES}

1. Kaur H, Kumar B, Medhi B. Antiepileptic drugs in developmentpipeline: a recent update. Neurol Sci 2016;4:42-51.

2. Rang HP, Dale MM, Ritter JM, Flower RJ. editors. Rang and dale's pharmacology. $6^{\text {th }}$ ed. New Delhi: Churchill Livingstone Elsevier; 2008.

3. Stafstrom CE, Carmant L. Seizures and epilepsy: an overview for neuroscientists. Cold Spring Harb Perspect Med 2015;5:1-18.

4. Denial HL. Seizures and epilepsies. In: Harrison's principles of internal medicine. Kasper DL, Fauci AS, Hauser SL, Lango DL, Jameson JL, Loscalzo J. editors. 17th ed. New York: Mc Graw Hill Education; 2008. p. 2498-512.

5. Ngugi AK, Bottomely C, Kleinschmidt L. Estimation of the burden of active and lifetime epilepsy: a meta-analytic approach. Epilepsia 2010;51:883-90.

6. Sinha SC. Medicinal plant of Manipur, Imphal: Manipur association for science and society; 1996.
7. Deb DB. Compositae (Asteraceae). The flora of Tripura state. $1^{\text {st }}$ ed. Vol. 2. New Delhi: Today and Tomorrow's Printers and Publishers; 1983.

8. Verma SCL, Agarwal SL. Studies on Leptadenia reticulata part II-preliminary chemical investigations. Indian J Med Res 1962;50:439-45.

9. Kokate CK, Purohit AP, Gokhale SB. editors. Pharmacognosy. $45^{\text {th }}$ ed. Pune: Nirali Prakashan; 2009.

10. Shah B, Seth AK. editors. Textbook of pharmacognosy and phytochemistry. $2^{\text {nd }}$ ed. New Delhi: Elsevier; 2014.

11. OECD. OECD guidelines for testing of chemicals 423: Acute oral toxicity-Acute toxic class method. Paris; 2001. Available from: https://ntp.niehs.gov/iccvam/suppdocs/feddocs/oecd/oecd gl423.pdf. [Last accessed on 14 Sep 2018]

12. Castel Branco MM, Alves GL, Figueiredo IV, Falcao AC, Caramona MM. The maximal electroshock seizure (MES) model in the preclinical assessment of potential new antiepileptic drugs. Methods Find Exp Clin Pharmacol 2009;31:101-6.

13. Kulkarni SK. Practical pharmacology and clinical pharmacy. Delhi: Vallabh Publications; 2008.

14. Gupta SK. Drug screening methods. $3^{\text {rd }}$ ed. New Delhi: Jaypee Brothers Medical Publishers (P) Ltd; 2016.

15. Remy M. "Why do medical researchers use mice?" Live Science. 2010. Available from: http://www.livescience.com/32860why-do-medical-researchers-use-mice.html. [Last accessed 10 Oct 2018]

16. Loscher W, Fassbender CP, Nolting B. The role of technical, biological and pharmacological factors in the laboratory evaluation of anti-convulsant drugs II, maximal electroshock seizure models. Epilepsy Res 1991;8:79-94.

17. Inan SY, Buyukafsar K. Antiepileptic effects of two Rho-kinase inhibitors, $\mathrm{y}-27632$ and fasudin in mice. $\mathrm{Br} \mathrm{J}$ Pharmcol 2008;155:44-51.

18. Bum EN, Nkantchoua GN, Njikam N, Taiwe GS, Ngoupaye GT, Pelanken MM. Anticonvulsant and sedative activity of leaves Senna spectabilis in mice. Int J Pharmacol 2010;6:123-8.

19. Xu X, Yu L, Chen G. Determination of flavanoids in Portulaca oleracea L. by capillary electrophosis with electrochemical detection. J Pharm Bio-Med Anal 2006;41:493-9.

20. Devi LR, Singh TS, Singh LW. Antifungal and phytochemical studies of Eupatorium brimanicum DC. Indian J Chem 2017;46:1868-72.

21. Paramdeep S, Damanpreet S, Rajesh KG. Phytoflavonoids: antiepileptics for the future. Int J Pharm Sci 2014;6:51-66. 